\title{
Suppressive Subtraction Hybridization on Stimulated Primary Horse Macrophages
}

\author{
J. MATIAŠOVIC ${ }^{1,2}$, P. KRÁLÍK ${ }^{1,2}$, L. LEVÁ $^{2}$, M. FALDYNA ${ }^{2}$, P. HOŘÍN $^{1}$ \\ ${ }^{1}$ Institute of Genetics, University of Veterinary and Pharmaceutical Sciences Brno \\ ${ }^{2}$ Veterinary Research Institute Brno
}

Received August 2, 2005

Accepted April 13, 2006

\begin{abstract}
Matiašovic J., P. Kralik, L. Levá, M. Faldyna, P. Hořín: Suppressive Subtraction Hybridization on Stimulated Primary Horse Macrophages. Acta Vet Brno 75, 2006: 337-341.

To study genes potentially involved in genetic resistance to infectious diseases in the horse, suppressive subtraction hybridization was used to identify genes expressed in primary horse macrophages after their stimulation with E. coli. Overnight culture of blood monocyte-derived macrophage cells was stimulated with $E$. coli $\mathrm{K} 12$ in ratio 40 E. coli cells to one macrophage cell. After 4 hours of incubation, non-phagocyted bacteria were washed away. Following next 20 hour incubation in MEM alpha containing $5 \mu \mathrm{g}$ of gentamycin in $1 \mathrm{ml}$ of media, mRNA was isolated and used in Clontech PCR-Select cDNA Subtraction Kit. Expression of several known horse genes, as well as some new ESTs (expressed sequence tags) showing sequence similarity with immunity-related genes from other species was identified.
\end{abstract}

SSH, horse, monocyte, immunity

Several methods can be used to identify differentially expressed mRNAs. Differential display, subtractive hybridization and serial analysis of gene expression (SAGE) are widely used methods. SAGE is probably the most powerful, and not only qualitative, but also a quantitative method (Pylouster et al. 2005). However, this method is also very expensive, due to the number of sequencing reactions needed. Differential display analysis uses acrylamide gels for separation and identification of ESTs (expressed sequence tags). The gel-based separation and subsequent DNA isolation represents an inconvenience of this procedure. Usually tens of ESTs are identified (Chakrabarti et al. 2002; Lee et al. 2003). Subtractive hybridization in combination with suppressive PCR can trap differentially expressed genes without needing physical separation of products of hybridization (ssDNA and dsDNA) (Diatchenko et al. 1996). The result of the whole procedure is a pool of PCR products representing ESTs.

Macrophage reactions to pathogens are mediated not only by the type of antigen, but they are also actively influenced by the pathogen. For example, M. tuberculosis decreases production of IL-12 in human primary monocyte-derived macrophages, while E. coli cells were found to be an activator of a wide range of genes in stimulated human primary monocyte-derived macrophages ( $\mathrm{Nau}$ et al. 2002).

The number of known immune-related genes in horse is limited. The objective of this work was to identify differentially expressed sequence tags (ESTs) in stimulated and/or nonstimulated horse macrophage cells.

\section{Materials and Methods}

Monocyte derived macrophage cells: a modified protocol of Raabe et al. (1998) was used. Briefly: 0.5 1 of whole blood from a healthy horse was centrifuged on Histopaque (Sigma-Aldrich, Germany)/Telebrix (Léčiva a.s., Czech Republic) mixture with density of 1.098. Peripheral blood mononuclear cells were placed on plastic dishes coated with $2 \%$ gelatine (Sigma-Aldrich, Germany) and incubated in MEM alpha (Sigma-Aldrich, Germany) supplemented with glutamine (Sigma- Aldrich, Germany), 10\% horse sera (Sigma-Aldrich, Germany) and $100 \mathrm{U} / 100 \mu \mathrm{g} / \mathrm{ml}$ of penicillin/streptomycin (PAA Laboratories, Austria). After 3 hours of incubating at $37^{\circ} \mathrm{C}$ with $5 \% \mathrm{CO}_{2}$, nonadherent cells were washed away. Adhered monocyte cells were incubated overnight.

Address for correspondence:

MVDr. Ján Matiašovic, Ph.D.

Veterinary Research Institute

Department of Immunology

Hudcova 70, 62100 Brno, Czech Republic

Phone: +420533331317

Fax: +420 541211229

E-mail:matiasovic@vri.cz

http://www.vfu.cz/acta-vet/actavet.htm 
Stimulation: Overnight culture of monocyte-derived-macrophage cells were stimulated with viable $E$. coli $\mathrm{K} 12$ in ratio of 40 bacteria to 1 macrophage cell in media without antibiotics. After four hours, cells were gently washed and incubated for 20 hours with media containing $5 \mu \mathrm{g} / \mathrm{ml}$ of gentamycin. After that, cells were lysed directly on dish with TRIReagent (Sigma-Aldrich, Germany). Changes in cell size and granularity were measured on flow cytometer (FACSCalibur, Becton Dickinson, NJ USA). Non-stimulated control cells were treated in the same conditions, except for the addition of E. coli into media.

mRNA isolation: mRNA was isolated from total RNA using Oligotex mRNA Mini Kit (Qiagen, CA USA).

Suppressive subtraction hybridization $(\mathrm{SSH})$ : isolated mRNA from stimulated and/or non-stimulated cells was used in suppressive subtraction hybridization. A Clontech PCR-Select cDNA Subtraction Kit (BD Biosciences, NJ USA) was used for this purpose. According to the manual, the forward and reverse subtracted probes were made for differential screening of subtracted products.

Differential screening of subtracted products: subtracted products were resolved on $1 \%$ agarose gel. DNA was blotted on Hybond N+ nylon membrane (Amersham Biosciences, Sweden) and hybridized with forward and/or reverse subtracted probes using AlkPhos Direct Labeling and Detection System with CDP-star (Amersham Biosciences, Sweden).

Cloning and sequencing: SSH products were cloned into pDrive vector (PCR Cloning kit, Qiagen, CA USA) and pCRXL vector (TOPO XL Cloning kit, Invitrogen, CA USA). Plasmids were sequenced in MWG company (Germany), while PCR products on ABI 310 (Applied Biosystems, CA USA) .

Blast analy sis: searches of obtained ESTs against sequences deposited to GeneBank/EMBL/DDBJ databases were performed with blastn software (Altschul et al. 1997, http://www.ncbi.nlm.nih.gov/BLAST/) using default parameters (low-complexity filter, word size 11, expect statistical significance threshold 10). ESTs with no hit to GeneBank/EMBL/DDBJ databases using blastn (ESTs DQ138065, DQ138061, DQ138064, DQ138063) were searched against human, mouse, cow, pig and dog genomes using cross-species megablast (expect statistical significance threshold 10, http://www.ncbi.nlm.nih.gov/genome/seq/HsBlast).

\section{Results and Discussion}

Changes in granularity and size of cells were observed by FACS after stimulation of primary horse macrophages with viable $E$. coli (Fig. 1). Using SSH, 7 fragments were
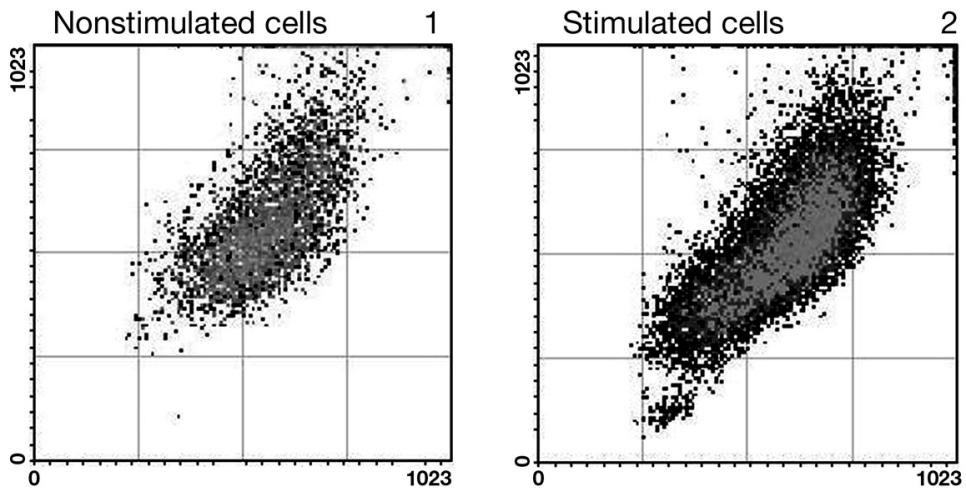

Fig.1. Side scatter (horizontal scale) represents cell granularity, forward scatter (vertical scale) represents cell size.

obtained from the cells after stimulation with $E$. coli, while 17 fragments were obtained from non-stimulated macrophages. Another 6 fragments were isolated from stimulated cells following a second independent $\mathrm{SSH}$. This is a relatively low number as compared to the number of genes known to be involved in the activation program of human macrophages ( $\mathrm{Nau}$ et al. 2002). This is probably due to a low efficiency of the procedure used. On the other hand, the number of genes differentially expressed after macrophage activation may be biased by macrophage activation caused by cell adherence on plastic dish, regardless of the presence of $E$. coli cells. Bands representing SSH products were cut out of the gel and 
reamplified for sequencing. As some bands could not be reamplified successfully, SSH products were cloned into pDrive and pCRXL vectors, and clones with different length of inserts were sequenced. Some genes were present in more than one fragment. The genes identified are summarized in Table 1. Four of 7 new sequences from stimulated cells represent putative horse chemokines, based on their homology with nucleotide sequences

Table1. ESTs identified in macrophage by SSH

\begin{tabular}{|c|c|c|}
\hline \multicolumn{3}{|c|}{ Products from stimulated cells } \\
\hline EST similar to & $\%$ of identity & accession number \\
\hline equine MGSA AF053497 & 98 & \\
\hline equine IL1beta ECU92481 & 98 & \\
\hline equine G-CSF AF503365 & 99 & \\
\hline human THBS1 NM_003246 & 96 & DQ138067 \\
\hline human CXC ligand 1 NM_001511 & 81 & DQ138062 \\
\hline human CXC ligand 5 BC008376 & 82 & DQ138068 \\
\hline porcine AMCF II NM_213876 & 87 & DQ138066 \\
\hline bovine GCP2 AF149249 & 88 & DQ138069 \\
\hline fragment 48 from SSH AY246812 & 100 & \\
\hline uknown sequence H9 & & DQ138065 \\
\hline unknown sequence $\mathrm{S} 7$ & & DQ138061 \\
\hline \multicolumn{3}{|c|}{ Products from non-stimulated cells } \\
\hline EST similar to & $\%$ of identity & accession number \\
\hline equine MGSA AF053497 & 98 & \\
\hline equine IL1beta ECU92481 & 98 & \\
\hline equine PAI 2 AF508790 & 99 & \\
\hline equine satellite TKY504 AF508790 & 94 & \\
\hline equine clone $37 \mathrm{c}$ AY029358 & 90 & \\
\hline equine clone $\mathrm{CH} 241-77 \mathrm{~F} 8 \mathrm{AC} 153071$ & 85 & \\
\hline $\begin{array}{l}\text { bovine genomic contig NW_351856 } \\
\text { and/or } \\
\text { human genomic contig NT_010393 }\end{array}$ & $\begin{array}{l}78^{*} \\
76^{*}\end{array}$ & DQ138064 \\
\hline unknown sequence N11 & & DQ138063 \\
\hline
\end{tabular}

*similarity found using cross-species megablast

from other species. It corresponds well to their function in macrophages stimulated with bacteria, which is also the case of the putative horse thrombospondin 1 (Narizhneva et al. 2005). Another fragment is identical with the GenBank sequence AY246812 [product 48 from SSH from an interleukin 1b treated equine synovium, Takafuji et al. (2003), published only as an GenBank entry]. Two other fragments were not homologous to any 
known sequences deposited in GenBank /EMBL/DDBJ using blastn, as well as to human, mouse, cow, pig and dog genomes using cross-species megablast. Presence of fragments containing non-coding sequences in products from non-stimulated cells was not anticipated (equine satellite TKY504 AF508790, equine clone 37c AY029358, equine clone CH24177F8 AC153071, EST DQ138063 and EST DQ138064 similar to bovine genomic contig NW_351856 and/or human genomic contig NT_010393), as contaminating DNA should not be present in mRNA samples due to mRNA preparation by hybridization of polyA tails to immobilized oligo-dT. Despite the fact that the first SSH Southern-blot hybridization with forward and reverse subtracted probes showed differential expression of the SSH products, the MGSA (melanoma growth stimulatory analog) and IL1beta genes were found in products from non-stimulated cells from the first SSH, but also in products from stimulated cells at the second $\mathrm{SSH}$, which is not in agreement with theoretical expectations. This may be considered as an example of false positive results representing a common problem of methods used for identification of differentially expressed genes (Chen et al. 2004). The results presented here thus showed that the efficiency and specificity of the used SSH protocol was not optimum. It seems that efficiency of the SSH procedure is very sensitive to reaction conditions and can be used only as a preparative, not analytical tool. However, obtaining 9 newly identified sequences showed that SSH may be a feasible genomic approach for identifying ESTs in horse macrophages, including the identification of so far unknown sequences. In summary, this approach showed that under the experimental conditions used in this study, macrophages express genes involved in chemokine signalling.

\section{Použití supresní subtrakční hybridizace na stimulované primární makrofágy koně}

Ke studiu genů s předpokládaným vlivem na genetickou rezistenci k infekčním nemocem koně jsme použili supresní subtrakční hybridizaci jako nástroj k identifikaci genů exprimovaných v primárních koňských makrofázích po jejich stimulaci $E$. coli. Kultura makrofágů odvozených z krevních monocytů byla stimulována $E$. coli K12 v poměru 40 bakteriálních buněk na 1 buňku makrofága. Nefagocytované bakterie byly po 4 hodinách kultivace odmyty. Po dalších 20 hodinách kultivace v mediu MEM alfa s přídavkem $5 \mathrm{mg}$ gentamycinu na $1 \mathrm{ml}$ media, byla izolována RNA a použita pro supresní subtrakční hybridizaci (Clontech PCR- Select cDNA Subtraction Kit). Kromě několika u koně již známých genů byly nalezeny nové sekvence podobné genům imunitní odpovědi známých u jiných živočišných druhů.

\section{Acknowledgement}

The work was supported by the Czech Science foundation (projects 523/02/D126 and 523/02/1526) and Ministry of Agriculture of the Czech Republic (project 0002716201). Thanks to Dr. Rychlík and Mgr. Gregorová from Veterinary Research Institute for direct sequencing of PCR products.

\section{References}

ALTSCHUL SF, MADDEN TL, SCHÄFFER AA, ZHANG J, ZHANG Z, MILLER W, LIPMAN DJ 1997: Gapped BLAST and PSI-BLAST: a new generation of protein database search programs, Nucleic Acids Res 25: 3389-3402

DIATCHENKO L, LAU YF, CAMPBELL AP, CHENCHIK A, MOQADAM F, HUANG B, LUKYANOV S, LUKYANOV K, GURSKAYA N, SVERDLOV ED, SIEBERT PD 1996: Suppression subtractive hybridization: a method for generating differentially regulated or tissue-specific cDNA probes and libraries. Proc Natl Acad Sci USA 93: 6025-30

CHAKRABARTI R, ROBLES LD, GIBSON J, MUROSKI M 2002: Profiling of differential expression of messenger RNA in normal, benign, and metastatic prostate cell lines. Cancer Genet Cytogen 139:115-25

CHEN Y, WANG B, WEINING S, DAGGARD G 2004: Anchor primer associated problems in differential display reverse transcription polymerase chain reaction. Anal Biochem 329: 145-147 
LEE SS, SEO HS, CHOI SJ, PARK HS, LEE JY, LEE KH, PARK JY 2003: Characterization of the two genes differentially expressed during development in human fetal astrocytes. Yonsei Med J 44:1059-68

NARIZHNEVA NV, RAZORENOVA OV, PODREZ EA, CHEN J, CHANDRASEKHARAN UM, DICORLETO PE, PLOW EF, TOPOL EJ, BYZOVA TV 2005: Thrombospondin-1 up-regulates expression of cell adhesion molecules and promotes monocyte binding to endothelium. FASEB J 19: 1158-60

NAU JG, RICHMOND JFL, SCHLESINGER A, JENNINGS EG, LANDER ES, YOUNG RA 2002: Human macrophage activation programs induced by bacterial pathogens. Proceedings of the National Academy of Sciences 99: 1503- 1508

PYLOUSTER J, SENAMAUD-BEAUFORT C, SAISON-BEHMOARAS TE 2005: WEBSAGE: a web tool for visual analysis of differentially expressed human SAGE tags. Nucleic Acids Res 33 (Web Server issue): W693-5

RAABE MR, ISSEL CJ, MONTELARO RC 1998: Equine monocyte-derived macrophage cultures and their applications for infectivity and neutralization studies of equine infectious anemia virus. J Virol Methods 71: 87-104 